Article

\title{
Images of Roma through the Language of Bulgarian State Archives
}

\author{
Aleksandar G. Marinov \\ School of History, University of St Andrews, St Andrews, KY16 9BA, UK; E-Mail: agm27@st-andrews.ac.uk
}

Submitted: 14 January 2020 | Accepted: 24 March 2020 | Published: 4 June 2020

\begin{abstract}
This research has been carried out as part of the Romalnterbellum Project which studies the Roma civic emancipation between World War I and World War II. Trawling through the Bulgarian archival documents on Roma in this time period, a reader cannot help but begin to form a certain image about the Tsigani, the term with which Roma have been popularly referred to in the archives. Unsurprisingly, this image does not seem to differ much from the one of today-that of the uneducated, dirty, foreign, and that pose a threat not only to the prosperity and well-being of the Bulgarian population and culture at large but also to the state and the economy. The research is based on archived files, letters of complaints from Bulgarian citizens and other documents sourced from Bulgarian state archives. The article analyses the words and language employed in the archived documents, the connotations they bear and the images they build. It also tries to show how, in the interwar period, this dominant language was utilised by Roma individuals and leaders in order to react, counter and protect their image and future. More importantly, they sought ways to build a better integrated Roma society through the establishment of own organisations and associations. Understanding this historical narrative from the interwar period is essential in advancing knowledge of many major issues surrounding the Roma today, such as housing, health and their social inclusion.
\end{abstract}

\section{Keywords}

Bulgaria; emancipation; Gypsy; inclusion; language; Roma; state archives

\section{Issue}

This article is part of the issue "Gypsy Policy and Roma Activism: From the Interwar Period to Current Policies and Challenges" edited by Elena Marushiakova (University of St Andrews, UK) and Vesselin Popov (University of St Andrews, UK).

(C) 2020 by the author; licensee Cogitatio (Lisbon, Portugal). This article is licensed under a Creative Commons Attribution 4.0 International License (CC BY).

\section{Introduction}

With the end of World War I, newly formed European states began to re-structure, re-organise and revisit their own visions for state and society. The interwar period marked the end of major empires, such as the Ottoman, Austro-Hungarian and the Russian and the redrawing of European borders. With that, all new states included in their borders substantial ethnic minorities including Roma, or Tsigani-as they have been popularly referred to at the time in Bulgaria-a term commonly translated as Gypsies.

What ought to be highlighted in the outset of this work is the geographical context and the history of the new Bulgarian state and its historical link to the Ottoman Empire. As Barany (2002) argues, imperial states would normally seek to be moderate and restrained towards their marginal groups. The Ottoman Empire would thus grant several rights to its various ethnic minorities such as to preserve their cultures, languages and religions. However, the Empire would be reluctant to give them political rights as its major concerns were to maintain political stability, keep or extend its territory, and collect taxes. For that reason, it is correct to assume that the treatment of Romani people in the Ottoman Empire has been characterised with relative negligence and tolerance which gave them freedom to preserve their culture and language and exercise their professions. This could be in opposition to other regimes which soughed to rid themselves, in various ways, of their Gypsies, or to assimilate them (Barany, 2002; Macfie, 1943; Margalit, 1999; Yates, 1966). In the Ottoman Empire, Gypsies enjoyed considerably better lives compared to other European regions. Nevertheless, Roma were relegated to the lowest level of the social scale together with those who could not have been identified as having a profession. In fact, the 
Romani people in the Ottoman Empire appear to have been treated and taxed as a distinct ethnic group, regardless of their religious affiliations-a practice which has been atypical for the Ottoman rulers (Marushiakova \& Popov, 2001). The dislike of Gypsies in the Ottoman Empire has also been based on their view as less reliable and trustworthy than other peoples, with the wandering lifestyle of part of the Gypsies to appear troublesome. Other images that have been popular in the Ottoman Empire included those of the Gypsy as useless parasites and, towards the end of 17 th century, as pimps and prostitutes which, in return, has resulted in increasing of the collected taxes (Malcolm, 1996; Todorova, 2009). As Bulgaria gained independence in 1878 from Ottoman rule, the social position of Gypsies declined further. This could be partly because most of them were followers of Islam which now became associated with the former oppressors and in opposition to Orthodox Christianity. After the end of World War I, Roma began to pursue a better future through a mixture of independence and adaptation to societies they lived with (Marushiakova \& Popov, 1993). That option included the adoption of the new religious (Protestant) identities and churches, and the foundation of associations, organisations and their own press (Marinov, 2019; Marushiakova \& Popov, 2015; Slavkova, 2007).

This article seeks to show that the civil emancipation of the Roma is rooted in a critical interplay between the predominant narrative of the state and its institutions and the Roma themselves who sought to balance that portrayal with their own narratives. It will show that despite the largely negative portrayal of Roma by the Bulgarian state, they managed to establish their own organisations and associations based on their own visions for their place in the society, furthering and protecting their own interests and seeking to secure a better future in Bulgaria. This article is composed of two parts: First, we will present the 'master narrative' of the Bulgarian state from the interwar period; second, we will deal with the ideas, imagery, narratives and proposals from Roma themselves based on the Bulgarian archival records from the interwar period.

\section{Seeing and Learning about Roma through the Eyes of Bulgarian State Archives}

The access to archival documents offers the potential of verifying already existing information but also the discovery of a new previously undiscovered information. This allows to certify the veracity of widely cited archival materials and re-analyse these same materials through the interpretation of the researchers themselves. Sadly, Romani studies has been viewed as a field where scholars would repeat previous information ad infinitum without verifying it and thus perpetuating erroneous knowledge (Clark, 2004; Hancock, 2004; K. Lee, 2004). While studying the archival documents of the Bulgarian state archives dealing with Roma in the interwar period, it was the language and descriptions of the Gypsies which made the greatest impression on the author and, as a result of that, the images that were formed by reading these records. For the purposes of this work, the author defines the term 'image' as the written descriptions of Roma in the Bulgarian state archives. Even though the state offers some photographic images of Roma from the interwar period, this work chose to analyse only the written documents and the stories they present. Thus, these stories-predominantly official state documents, memos, notes, petitions, internal communications-have been referred to here as 'master narratives' so much so that they have been sourced by the official Bulgarian state. If for a second we imagine the reader had no prior knowledge or information about the Gypsies, and reading these archival documents were their sole point of departure, they would have most certainly been able to form a complete image of who the Gypsies in Bulgaria were-thanks to the presentation and the portrayal found in the documents. That image is so complete, as argued by this work, that it does not differ much from the mainstream image of the Roma in the present day and age. For contemporary images see the works of Ivasiuc (2019) and van Baar, Ivasiuc, and Kreide (2019). This article should be considered as a snapshot as it focuses on the presentation of a specific, yet important, timeframe in the history of Bulgaria and the civic and social emancipation of their Roma.

This research supports the argument of certain scholars such as Lucassen and Willems (2003), Lucassen, Willems, and Cottaar (1998), and Willems (1998) that the identity of Gypsies is a social construct. The scholars have come to their conclusion based on their research in Prussia, the German state after its unification in 1871, and the Netherlands. In their work, the authors found that vagrants, vagabonds, travellers, Gypsies and other unwanted 'social ills' were all seen as equally bad and threatening to the 'well-ordered societies' of the West. As they have put it, the concept of a "well-ordered society" is largely a Western one (Lucassen \& Willems, 2003, p. 307). The Gypsies, (poor) travellers and vagrants have been threatening to the state because of their lack of permanent residences, the inability to be monitored, and ultimately with their posing need to be supported by the state.

In the context of Bulgaria, at least as the Bulgarian state archives have demonstrated, nothing suggests that the term 'Gypsy' is being conflated with other groups and there is no doubt who is a Tsiganin (a Gypsy) and who is not. This research also reinforces the statement of Marushiakova and Popov (2017) who have argued that in Eastern Europe there is no doubt about who the Gypsies are and who exactly belongs to that group. The documents are able to discern those Roma who are sedentary, nomadic, those who come from abroad, and even those who may have preferred to hide their true Romani identities. Even though the ethnic aspect of the Roma is only slightly touched upon in the archival sources, i.e., that 'Gypsies' are a people with distinct 
language, culture and origins, there seems to be no reference to the 'dubious' character of 'the Gypsies,' nor to the complex identities of the Roma. Some authors, such as David Mayall (2004), have managed to show that the identity of the Gypsy is laden with complexities and that often non-Roma "outsiders" would disagree on many of their socially constructed identities (p. 278). Without giving credibility to any of their contested identities, Mayall (2004) shows that knowledge, information and common beliefs about Gypsies have become historically accepted as 'credible.' In fact, the gathered Bulgarian documents appear to have a quite rigid perception of a certain group of people called Tsigani whose portrayal is of 'invaders' and 'infesters' who do not belong nor fit adequately in the Bulgarian society, prosperity and future. Somehow similar to this is the work of Susan Williams (2007) who examined the period between 1918-1934 and the disparity between the visions of non-Roma, largely western Gypsylorists (who wanted to see and experience the 'true' Gypsy of Eastern Europe, who were perceived as unaffected by the nascent modernity of the time), and Romanian Roma intelligentsia themselves (who furthered their visions as good and loyal Romanians, Orthodox in religion, and forming trade unions, organisations, and associations who tried to promote a new Roma identity opposed to the 'backward' nomadic Roma groups and lifestyle).

Probably, the sole image of Gypsies which resonates universally nowadays in the East and the West is that of the travellers. Lucassen and Willems (2003) distinguish between nomadic groups who travel alone or in small groups in order to exercise their professions and offer their services to the settled population, and those who travel with their families. Even though both sets of groups are stigmatised equally, based on their research on reports and journals of criminologists in Germany, itinerant professionals, such as show-people, musicians, jugglers, bear leaders, coppersmiths and peddlers who travel with their families are more likely to be labelled with the more stigmatic term 'Gypsies.' Furthermore, the authors manage to show that the two sets of groups have been popularly confused with one another and that there is no clear way to distinguish between the two as both groups have been equally distrusted and stigmatised. In fact, the authors noticed an increase of the use of the term 'Gypsies' in the German police journals after 1830 s onwards, suggesting that the term has been used as a category to be applied more generously to any rogue, poor, alien and travelling person.

The collected Bulgarian archival records are not criminological per se even though there are documents which are communications by police inspectorates who too appear to treat Gypsy nomadism as undesired, linking it with illegality and criminality. The records appear to be quite certain about who Gypsies are, but at the same time they are ambiguous and inclusive in their description regarding who they include in the term 'Gypsy.' The Bulgarian state, like the ones in the West, seems to be equally threatened and appalled by the movement of Gypsies. For example, the Draft Bill for the Abolition of the Wandering of Gypsy Nomads, first proposed 1937 and changed in the next couple of years, clearly suggests that the travels of nomad-Gypsies in Bulgarian lands must be legally outlawed. Gypsy nomads in Bulgaria are described in Article 1 of the bill as:

All Tsigani with unsettled address, who wander around the Kingdom and live in camps or in the open air, regardless of what kind of occupations they practice. (“Draft bill," 1937)

A quite informative part of this draft bill is another supplementary document entitled Rationale for the Bill for the Abolition of the Wandering of Gypsy Nomads. Here, the great number of Gypsies roaming the Bulgarian Kingdom is stressed from the outset. The document does not vow to cite an exact figure and only says "tens of thousands." Gypsy nomads are described as having:

The most diverse professions-whittlers, spindlemakers, comb-makers, bear-leaders, monkey-leaders etc. ("Rationale for the bill," 1941)

These professions, however, are seen just as disguise of their real professions which are cited as:

Theft and begging which are skilfully concealed with the dancing of monkeys, bears and with all kinds of exorcism and fortune-telling. ("Rationale for the bill," 1941, p. 48)

Also, the nomad-Gypsies are characterised as criminals stealing animals and children and as "bearers of the most-dangerous and contagious diseases, both among people and among domesticated animals" ("Rationale for the bill," 1941, p. 48). Here, because of their mobile lifestyle, Gypsies' perceived criminal activities are reported as hard to discover and difficult to persecute. Like the older existing records about the Gypsies, in Bulgaria too, the nomad-Gypsies are popularly perceived to be a 'great social ill' because of their spread of diseases, immorality and prostitution, corrupting the upstanding morals of the good Bulgarian citizens.

There are also a few archival documents that precisely deal with the perceived threat of nomadGypsies in Bulgaria. A complaint from 1938-written on behalf of the local residents in Sofia and by the Sofia's Neighbourhood Cultural-Charitable Association Ivan Krastitel-alerts the police and the Department of Health about the presence of Gypsy nomads occupying the area around the Vladaya River and Dobrotich Street in Sofia. The presence of the Gypsies is characterised in the letter as the cause of rubbish, misery, disease, bad behaviour and negative influence for the younger Bulgarian generation. The letter asks these Gypsies to be confined in the outskirts of the city or isolated in the 
Gypsy neighbourhood Fakulteta, where it would be wellfitting for this negative and undesired behaviour. This, for example, essentially conveys that it is not only nomadGypsies that are undesired and threatening to the cultured Bulgarian population but Gypsies in general. The indication that the Gypsy newcomers shall fit well in the settled neighbourhood of Fakulteta, in the outskirts of the city, indicated the marginalisation of the two groups. In its rationale, the complaint letter conveys the common knowledge about the Gypsies in general:

You [Chief of police] must be aware, that the Gypsies are a people/nation [narod], which does not bend under any culture and education, neither it must be expected the performance from them of any discipline, hygiene, order, under which the mass, collective way of life is characterised with. That is why, for a long time they are being eliminated by the other citizens and are being settled in the outskirts of the towns, they are being isolated. ("A request letter," 1938, p. 1)

Similarly, Picker (2017) has argued in his work that there is a link between racialised urban segregation and racialised representations, policies and control. He demonstrated how the symbolic, spatial, marginalisation of Roma situates them into harmful socio-economic conditions and health, and how such state policies are informed and justified by a certain prejudice or racist understanding. Interestingly, today the largest Romani neighbourhood in Sofia is Fakulteta-a neighbourhood which is not considered to be in the outskirts of the capital in today's standards. It also continues to be a spatial entity which hosts many Roma from Bulgaria's provinces who seek to settle down and work in the capital.

Reading through the archives, it becomes apparent that Gypsies in general, regardless of their lifestyle, are the problematic 'other.' A letter sent in 1941, from the Sliven Economic Association in the town of Sliven, addressed to the Minister of Internal Affairs and National Health of Bulgaria writes:

Populated since time immemorial, occupying the most hygienic part of the town's surrounding area, scattered about in hovels and huts rotting in dirt and in stench-the Gypsies, with their illbreeding and lack of feeling even about the tiniest of responsibilities-already pose one huge threat in all kinds of respects to the rest of the population of the town. ("A letter from the Sliven Economic Association," 1941, p. 2)

The document further cites the perceived dangers of the Gypsies, such as the spreading of diseases, begging, stealing of jobs in the textile factories from ethnic Bulgarians, not contributing to the Bulgarian economy with taxes, spreading of amoral behaviour, and their criminality. The image of Gypsies as bearers and disseminators of contagious diseases is well-documented in the archives and some documents even suggest that to be known as common sense. Their perceived image as 'dirty' could thus further explain the tone of the letter and its request for Gypsies to be displaced away of the town or from Sliven. Indicative and more detailed, for example, is the complaint letter by the Neighbourhood Cultural-Charitable Association Ivan Krastitel, from 1938, which refers to the damages done to the Bulgarian residents by the presence of Gypsy occupants in their neighbourhood:

It is enough these couple of Gypsy families - to transform [the whole neighbourhood], and it is already transformed, into a Gypsy mahala [neighbourhood] streets, water taps, public places, water-are polluted, which all create the full conditions for the emergence of some serious epidemic disease, which eventually may kill many and reach the centre of the city. Regarding their morale and the examples that our children would receive from their children-we should not speak: the most vulgar swearing, fights, drunkenness, debauchery-everything [which is from] the worst. ("A request letter," 1938, p. 1)

These lines above and the story they present of Roma as posing serious threats to the society at large resonate quite strongly at the time of writing this article. More than 80 years since the appearance of these archival documents, this narrative remains unchanged. At the time of writing this article and at the outset of the Covid-19 disease as observed in Eastern Europe, Roma have received special attention. On the one hand, there is the presumption that, generally, Gypsies have poor hygiene, and on the other hand that they are not well-informed and educated. These two aspects combine to form an image of the Roma as a group which requires policing, to be controlled, feared and ridiculed. Roma have received special media and political attention at the time when government measures have been taken towards the containment of the new highly contagious virus. It seems that just as there is the need to contain the virus, Roma had to be contained too. For instance, in Bulgaria there have been televised interviews with members of the Romani neighbourhoods, of various ages, who were being asked whether they know what coronavirus is and what they do so that they do not contract it. At the same time, Bulgarian authorities have put special measures to police the Romani neighbourhoods around the country in order to keep their residents within the borders of their neighbourhoods with the fears that they will spread the coronavirus. Even though at the time of the writing of the article there have been no officially reported cases of Roma who have contracted the virus, Roma communities in Bulgaria received stricter measures of vigilance and security while the nationalist party Bulgarian National Movement, which is part of the ruling coalition Government, has called Roma communities throughout the country to be quarantined and isolated due to their lack of discipline (Nikolov, 2020). Nine Roma musi- 
cians who have tried to return to their home in North Macedonia have also received special treatment at the outbreak of the pandemic. They are seen as the first people to be quarantined at the North Macedonian border and the only ones amongst the group of 200 people returning from Italy and Austria. Even though the Roma musicians have not shown any symptoms of having contracted the virus and have signed declarations to self-isolate in their homes, a posted video shows that they have been the only ones held and quarantined (J. Lee, 2020). Notable also has been the response of the Norwegian authorities who have arranged a special flight and have honoured the request of 140 homeless Roma to return to their Romanian homes at the outbreak of the recent global pandemic ("Oslo charters," 2020). The suggestion here is, in my interpretation, that these Roma, who have become a feature of the streets of Norway since 2007, could transmit the highly contagious virus and pose a further burden to the Norwegian state. There thus may be observed a persistent and general link between the (perceived mobile) lifestyles of Roma and the dangers or threats they pose to the society at large.

Finally, there are several documents showing that the Gypsies are considered to be poor and uneducated. There are documents exchanged between Bulgarian state departments trying to figure out how to keep Roma pupils enrolled at school. For example, in 1930, at the instance of the missing of 90 Roma pupils from the primary school, in the Dolna (Lower) Gypsy neighbourhood of the town of Kyustendil, the Head Teacher of the School, At. Shopov, has tried everything to keep the Roma pupils at school: This included seeking the help of the police and bringing pupils back with the help of police, issuing fines to their parents, and personal visits to their places of residence-all these efforts proved be in vain. It appears that the pupils were absent as they have been helping their parents to earn a living by being shoe polishers, porters, and begging, including in the cold winter months. The few Roma pupils, on the other hand, who were attending school are reported to be without shoes and with torn clothes, even in the harsh winter while literally starving. As a result, just to show the incompetence of the Bulgarian government to deal with the issue, the Bulgarian authorities ultimately decided to simply issue a fine to the primary school itself and cite its negligence of a Bulgarian Law for National Education ("Report from Dr. Slavchev," 1930). Section 2 could clearly be linked with many of the issues surrounding Roma today. The areas which are often identified as needing attention are their housing, health and education. It appears, however, that these issues are not new at all and coming up with well-drafted legislature may be not enough in addressing what seems to be a complex structural issue.

\section{Roma-Led Narrative and Activism}

The section above shows how Bulgarian Roma have been largely described as foreign, invaders with threatening traits, bearers of diseases both in humans and animals, with low, or no culture, which burdens and threatens, including financially, the Bulgarian society at large. While conducting archival research on the Roma civic emancipation between the two World Wars in Bulgaria, we were able to find another narrative, even though less vocal, which comes from the Roma themselves. It appears that the Gypsies of the time had a narrative of their own, and that they sought to exercise their rights and pursued their interests both individually and collectively.

On the individual level there have been initiatives undertaken by Roma which sought to settle down and get a workspace. The Protocol Book from the Meetings of Town Council of the town of Orhanie (nowadays Botevgrad), for example, tells about a request in 1924 by the Gypsy shepherd Miko Banov who asked for a plot of land to be used for living. The Council granted his wish because he lived with his brother in one room hosting 16 people. Banov thus received 200 square meters in the local Gypsy neighbourhood in order to prevent the emergence of diseases while living in a crammed space with his brother's family and also because "Miko Bonev is one good community shepherd" ("Protocol book," 1924, p. 94). In the same document, we read the request by a Gypsy, Miko Ramkov, living in the town Orhanie who asks the town Council for a plot of land for which he would pay. He asks for about 200 square meters in the Gypsy neighbourhood but separate from the remaining homes in order to avoid fires while being used as his smith workplace. Ramkov's wish has been granted. There is another request, this time by the Gypsy-nomad Duro Tsokov, asking for a plot of land in the Gypsy neighbourhood in order to settle down. On the grounds that he has not been a resident of Orhanie and due to the concerns that if the Council granted his wish this would become a precedent and "there would be many applications for plots from the Gypsies from the neighbouring villages," the Council of Orhanie refused Tsokov's application ("Protocol book," 1924, pp. 95-96).

On the collective level, we can witness the establishment, or at least the endeavours, of Roma organisations and professional associations which bore their own visions and sought to pursue their interests. Furthermore, there are examples where Roma tried to contest some of their portrayed images and to eradicate false rumours. The Statute of the Egyptian Nationality in the town of Vidin from 1910 included all Gypsies from the district and did not distinguish between religious affiliation of its members. It envisaged a leader to be appointed via the casting of a ballot among nine persons who were town leaders. Among the planned duties of the leader are:

To represent the [Gypsy] group to the country's authorities, all public organisations, other associations and third parties;...to preserve the common moral and material interests of its compatriots, to support them and to advocate for their legal protection;...to inspire civil consciousness among his people;...to work 
toward finding work for the poor people and when needed to provide first aid;...to keep an eye for the good intellectual, healthy and civil up-bringing of the non-old. ("Statute of the Egyptian nationality," 1910, pp. 6-7)

The idea of the leader should not be considered as new or unique. Rather, it is a continuation of an old practice which traces back to the Bulgarian Roma in the Ottoman Empire, where leaders would be chosen by the inhabitants of the Roma neighbourhood and recognised by the official authorities. That practice has been implemented so that the Romani communities could be controlled by the official authorities and it is notable that it continued to exist in the new and independent Bulgarian state. Seemingly, the idea of the Roma civic emancipation, according to the Association of the Egyptian Nationality in the town of Vidin, resulted in the need to continue in the old spirit and traditions and elect their leader, who would have a special role in dealing with the Romani community and the Bulgarian state. In that regard, there were several records found in the archives in the town of Montana, at the time called Ferdinand, which mention the appointment and the removal of posts of leaders in the Gypsy neighbourhoods. We also learnt that the Statute of Common Charitable Association for the Building of a Public Home and the Help of Poor Families of the Baptised Gypsies "Father Paisii" in the village Vasilovtsi, Lom district, has been approved on 22 August 1939. The Common Charitable Association sought to help the poor families of baptised Gypsies in the village of Vasilovtsi, Lom district, to organise them socially and serve for their moral and mental upbringing, and to offer financial assistance to its members. It sought also to establish a Gypsy charity which would serve for the moral and mental upbringing of the youth, to get a property for its headquarters, to share knowledge, and to give advice and settle disputes between its members ("Statute of the Common Charitable Association," 1938). Unfortunately, apart from its statute and official papers for approval, we do not know whether any of its plans and visions came to fruition.

Also, we can see the application of the Branch Tinsmith Craftsmanship Association Balkan, from the town Veliko Tarnovo, sent to the Minister of Internal Affairs and National Health in 1938. The letter asks the Minister to approve and acknowledge the existence of their association. We learn that the constitutive meeting of the association has taken place on 7 May 1935 in Veliko Tarnovo in the café of Ali Mahmudov Mutev. Its temporary chairman was Mustafa Mustafov, while the secretary was Ibrahim Z. Hyusmenov ("Application from the managing body," 1938). The Pleven Regional Directorate, in a letter to the Ministry of Internal Affairs and National Health, expressed the opinion that its statute should be approved as the persons from its management were deemed as "trustworthy and honest" ("A letter from the Pleven Regional Directorate," 1938, p. 21).
Another example of the collective endeavours of Roma pursuing their interests is a document written on behalf of eighty Roma families, tobacco workers in the town Gorna Dzhumaya. The petition was a reaction to a recent decree from the Bulgarian Minister of Labour which gave rights to the Inspectorate of Labour to lay off the Gypsy tobacco workers from Gorna Dzhumaya. The letter is addressed to a number of ministries in Sofia and states that the laying off of the Gypsy workers is ungrounded and unfair especially as the Gypsy families have been removed from work without any prior notice, just before the outset of the winter season, and because the Roma tobacco workers have proven to be reliable, experienced, and long-term workers who have no obligations to the country. The decree is deemed by the Roma as unfair as they claim that they do not have savings or any other means to earn a living and feed their families ("Statement from the families," 1941).

The passages above show a counter-narrative presented by the Roma themselves who, on the one hand, demonstrate civil consciousness and on the other an image which portrays them as honest, hard-working, and willing to work. Another informative initiative which has endeavoured to clear some of their images, refute false claims, and also further the interests of the Gypsies from Sofia, has been the Common Muslim CulturalEducational Organisation Istikbal (Future). For instance, on 6 March 1930, it reacted to published articles of two Bulgarian newspapers-Naroden Priyatel (People's Friend) and Utro (Morning) published in February and March of the same year. According to the statement of Istikbal, the real purpose of the articles has been to further a negative image about the "Muslim residents," i.e., Roma, so that they would be evicted while their land plots (that they legally owned) would be taken away. The letter sternly rejects the claims that the capital's Gypsy neighbourhood is a nest of various diseases and points out that in the hospitals of Sofia there are no registered Gypsy patients with any contagious diseases who are residents of the neighbourhood. Morally, too, the organisation describes the residents - the written piece equates the designation "Gypsies" with "pariah" - as humble and poor Muslims with strict values and it points out that in the Police Department of Morality in Sofia, there is not a single Gypsy woman registered ("Moods and truths," 1930, p. 1).

Later, in 1938, according to an article in the newspaper Dnevnik (Diary) the disease Typhus has appeared among the Gypsies in Sofia. Istikbal again reacted and emphasised that as far as the Roma neighbourhood, Konyovitsa, in Sofia is concerned, there has been only one registered patient, who in fact was a resident from the village of Vrabnitsa, near the town of Pernik. All other Gypsy residents in the neighbourhood have been inspected by the sanitary authorities which has not found any other patients. Istikbal's letter sought to eradicate and counter the spread of false rumours so that Gypsy working professionals from Sofia were not unjustly 
affected-workers such as porters, shoeblacks, basketmakers, florists, etc. The reaction letter maintains that the claims of newspaper Dnevnik's article are groundless news which bear a deeper meaning-it seeks to get rid of the residents of the neighbourhood in Konyovitsa, and is part of a number of attempts that can be traced back ten year earlier. In its letter, Istikbal explains that in 1929 a committee formed in this neighbourhood began to fight against the Gypsies so that they are put out of their houses. In 1938, a similar committee also existed, called Podem (Boom/Revival) which had the same objectives. According to Istikbal's letter, all these endeavours must be eradicated and are utterly unnecessary because they stir the passions of all Bulgarian citizens and create embitterment which are not necessary to anybody ("A clarification," 1938).

\section{Conclusion}

The Bulgarian archives from the interwar period show that the images of Roma are not much different to those universally observed in Eastern and Western Europe. Their old and universal images seem to have remained largely unchallenged-a group of people who poses many threats to the good and social order of the societies at large. Bulgarian state archives describe them as criminals and parasites who need to be contained and isolated, especially as they are perceived as poorly educated and misers responsible for disseminating contagious diseases. Thus, Roma in the past and today have been often portrayed as threatening and incompatible with the values and culture of Bulgarians. The article argued that in the interwar period these general narratives were in fact challenged by other archival records which showed that Roma sought to settle down, earn an honest living, and in fact have been considered by some official authorities as reliable and trustworthy. Roma in the interwar period offered an alternative image as they managed to establish organisations and associations with which sought to further their own interests and a better standing in the Bulgarian society. At the same time, they sought to counter and refute false rumours and narratives while presenting an alternative story and image about themselves. This reading of history points directly to a few relevant issues surrounding the issue Roma inclusion today. National European strategies too have identified housing, education, and health as key areas that need attention. Contemporary social perception, too, continues to view Roma as threating not only with their perceived low hygiene but also their low culture which is contrary to and polluting the morale and health of the society at large.

\section{Acknowledgments}

This article is written as a part of the research project 'Romalnterbellum. Roma Civic Emancipation between the Two World Wars' which has received funding from the European Research Council (ERC) under the
European Union's Horizon 2020 research and innovation programme (grant agreement No 694656). It reflects only the author's view and the agency is not responsible for any use that may be made of the information it contains.

\section{Conflict of Interests}

The author declares no conflict of interests.

\section{References}

A clarification from the Sofia Muslim EducationalCultural [Cooperative] Organisation "Istikbal"/ Future. (1938, March 16). Central state archive (f. $1 \mathrm{k}$, op. 4 , a.e. 531, I. 5.). Bulgarian State Archive, Sofia.

A letter from the Pleven Regional Directorate, Pleven, to the Ministry of Internal Affairs and National Health, Sofia. (1938, September 27). Central state archive (f.264k, op. 2, a.e. 5204, I. 21.). Bulgarian State Archive, Sofia.

A letter from the Sliven Economic Association to the Minister of Internal Affairs and National Health. (1941, September 10). Central state archive (f. 190k, op. 3, a.e. 114, I. 2-2back.). Bulgarian State Archive, Sofia.

$A$ request letter from the neighborhood CulturalCharitable Association "Ivan Krastitel", Sofia, to the head of 10th police station]. (1938, March 30). Central state archive (f. 1 k, op. 4, a.e. 531, I. 1-1back.). Bulgarian State Archive, Sofia.

Application from the managing body of the Branch Tinsmith Craftsmanship Association "Balkan," town V. Tarnovo. (1938, June 6). Central state archive (f.264k, op. 2, a.e. 5204, I. 5-10.). Bulgarian State Archive, Sofia.

Barany, Z. (2002). The East European Gypsies: Regime change, marginality, and ethnopolitics. Cambridge: Cambridge University Press.

Clark, C. (2004). 'Severity has often enraged but never subdued a gypsy': The history and making of European Romani stereotypes. In N. Saul \& S. Tebbutt (Eds.), The role of the Romanies: Images and counterimages of 'Gypsies'/Romanies in European cultures (1st ed., pp. 226-246). Liverpool: Liverpool University Press.

Draft bill for the abolition of the wandering of Gypsynomads. (1937). Central state archive (f.190k, op. 3, a.e.114, I. 7-8.). Bulgarian State Archive, Sofia.

Hancock, I. (2004). The concoctors: Creating fake Romani culture. In N. Saul \& S. Tebbutt (Eds.), The role of the Romanies: Images and counter images of 'Gypsies'/Romanies in European cultures (1st ed., pp. 85-97). Liverpool: Liverpool University Press.

Ivasiuc, A. (2019). Sharing the insecure sensible: The circulation of images of Roma on social media. In $\mathrm{H}$. van Baar, A. Ivasiuc, \& R. Kreide (Eds.), The securitization of the Roma in Europe (pp. 233-259). London: Palgrave. 
Lee, J. (2020, March 19). Roma quarantined at the border to North Macedonia. European Roma Rights Centre. Retrieved from http://www.errc.org/news/romaquarantined-at-the-border-to-north-macedonia

Lee, K. (2004). Belated travelling theory, contemporary wild praxis: A Romani perspective on the practical politics of the open end. In N. Saul \& S. Tebbutt (Eds.), The role of the Romanies: Images and counter images of 'Gypsies/Romanies in European cultures (1st ed., pp. 31-50). Liverpool: Liverpool University Press.

Lucassen, L., \& Willems, W. (2003). The weakness of wellordered societies: Gypsies in Western Europe, the Ottoman Empire, and India, 1400-1914. Review, 26(3), 283-313.

Lucassen, L., Willems, W., \& Cottaar, A. (1998). Gypsies and other itinerant groups: A socio-historical approach. London: Palgrave Macmillan.

Macfie, R. A. S. (1943). Gypsy persecutions: A survey of a black chapter in European History. Journal of the Gypsy Lore Society, 12(3/4), 65-78.

Malcolm, N. (1996). Bosnia: A short history. New York, NY: New York University Press.

Margalit, G. (1999). The image of the Gypsy in German Christendom. Patterns of Prejudice, 33(2), 75-85. https://doi.org/10.1080/003132299128810560

Marinov, A. G. (2019). The rise of Protestantism and its role within Roma communities in Bulgaria between the World Wars. In M. Slavkova, M. Maeva, Y. Erolova, \& R. Popov (Eds.), Between the worlds: People, spaces and rituals (Vol. 1, pp. 360-385). Sofia: Paradigma.

Marushiakova, E., \& Popov, V. (1993). Tsiganite v Bulgaria [Gypsies in Bulgaria]. Sofia: Club ‘90.

Marushiakova, E., \& Popov, V. (2001). Gypsies in the Ottoman Empire: A contribution to the history of the Balkans (O. Apostolova, Trans.). Hatfield and Hertforshire: University of Hertfordshire Press.

Marushiakova, E., \& Popov, V. (2015). The first Gypsy/Roma organisations, churches and newspapers. In M. Kominko (Ed.), From dust to digital: Ten years of the endangered archives programme (pp. 189-244). Cambridge: Open Book Publishers.

Marushiakova, E., \& Popov, V. (2017). Orientalism in Romani studies: The case of Eastern Europe. In $\mathrm{H}$. Kyuchukov \& W. New (Eds.), Languages of resistance: Ian Hancock's contribution to Romani studies (pp. 187-237). Munich: Lincom Europa.

Mayall, D. (2004). Gypsy Identities, 1500-2000: From Egyptians and moon-men to the ethnic Romany. London: Routledge.

Moods and truths: To the attention of our country, the Sofia municipality and the society. (1930). Central state archive (f. $1 \mathrm{~K}$, op. 2 , a.e. 831 , l. 1-1back.). Bulgarian State Archive, Sofia.

Nikolov, K. (2020, March 20). Bulgarian authorities struggle to enforce containment with Roma population. Euractiv. Retrieved from https://www.euractiv. com/section/languages-culture/news/bulgarianauthorities-struggle-to-enforce-containment-withroma-population

Oslo charters flight to return homeless Romanians due to coronavirus. (2020, March 18). The Local. Retrieved from https://www.thelocal.no/20200318/ oslo-charters-flight-to-return-homeless-romanians

Picker, G. (2017). Racial cities: Governance and the segregation of Romani people in urban Europe. London and New York, NY: Routledge.

Protocol book from the meetings of Orhanie town council. (1924, September 9). Central state archive (f. 225K, op. 1, a.e. 7, I. 94-96.). Bulgarian State Archive, Sofia.

Rationale for the bill for the abolition of the wandering of Gypsy nomads. (1941, June 28). Central state archive (f.190k, op. 3, a.e.114, I. 49-50.). Bulgarian State Archive, Sofia.

Report from Dr. G. K. Slavchev, Chief Inspector, to the Minister of National Education, Sofia. (1930, May 7). Central state archive (f.177k, op. 1, a.e.48, I. 156-156back.). Bulgarian State Archive, Sofia.

Slavkova, M. (2007). Tsiganite evangelisti v Bulgaria [Evengalical Gypsies in Bulgaria]. Sofia: Paradigma.

Statement from the families of 80 Gypsies-tobaccoworkers in the town of Gorna Dzhumaya. (1941, November 2). Central state archive (f.190k, op. 3, a.e.114, I. 47-47back.). Bulgarian State Archive, Sofia.

Statute of the Common Charitable Association for the building of a public home and the help of poor families of the baptised Gypsies "Father Paisii" in the Village Vasilovtsi, Lom District. (1938). Central state archive (f.264k, op. 6, a.e. 1461, I. 2-14.). Bulgarian State Archive, Sofia.

Statute of the Egyptian nationality in the town of Vidin. (1910). Specialised Library of the Studii Romani Archive (ASR), Sofia, Bulgaria.

Todorova, M. (2009). Imagining the Balkans. New York, NY: Oxford University Press.

van Baar, H., Ivasiuc, A., \& Kreide, R. (2019). The European Roma and their securitization: Contexts, junctures, challenges. In $\mathrm{H}$. van Baar, A. Ivasiuc, \& R. Kreide (Eds.), The securitization of the Roma in Europe (pp. 1-25). London: Palgrave.

Willems, W. (1998). In search of the true Gypsy: From Enlightenment to final solution (D. Bloch, Trans.). London: Routledge.

Williams, S. (2007). The "civilized trap" of modernity and Romanian Roma, 1918-1934. The Anthropology of East Europe Review, 26(2), 12-27.

Yates, D. E. (1966). The Pope and the Gypsies. Journal of the Gypsy Lore Society, 45(3/4), 73-76. 


\section{About the Author}

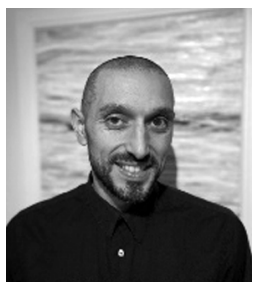

Aleksandar G. Marinov is a Postdoctoral Researcher in the School of History, University of St Andrews. His research interests gravitate towards Romani mobilities, identities, culture, and their civic emancipation. 